\title{
First report of grapevine red globe virus in grapevine in Iran
}

\author{
Shaheen Nourinejhad Zarghani ${ }^{1,2}$ (D) Maryam Khalili ${ }^{3,4} \cdot$ Akbar Dizadji $^{3} \cdot$ Thierry Wetzel $^{2}$
}

Received: 17 June 2020 / Accepted: 18 January 2021 / Published online: 27 January 2021

(c) Società Italiana di Patologia Vegetale (S.I.Pa.V.) 2021

Keywords Maculavirus · Tymoviridae $\cdot$ Grapevine $\cdot$ Primer

The grapevine red globe virus (GRGV) is a tentative member of the genus Maculavirus in the family Tymoviridae. The GRGV was first reported from Italy and since then from several other countries (Abou Ghanem-Sabanadzovic et al. 2003). To investigate the presence of GRGV in Iran, a total of 52 grapevine leaf samples showing symptoms of yellow mosaic and vein banding were collected from several locations in five provinces of Iran. GRGV was detected in 9 out of the 52 samples by RT/PCR using GRGV-specific primers (Ruiz-García et al. 2018), as well as general primers for tymovirids (Komínek et al. 2009). The RT/PCR product obtained with the GRGV-specific primers of an isolate from Tabriz (GRGV-Tab) was cloned and sequenced (GenBank accession No. MN232826). The resulting sequence was $91 \%$ identical to the German GRGV isolate (MG779496) and 90\% to the reference isolate Graciano-T101 (NC_030693). Two additional primer sets, GRGV-1560 s (5'GCATTG GATCCGCACCAATG3') and GRGV-2850as (5'CAAGAA GTTGTAGATGGTGGC3') designed for the amplification of the $5^{\prime}$-terminal part of the replicase gene, and GRGV$5550 \mathrm{~s}$ (5'GAAGAGAAGAAGGCCTCCTACC $\left.3^{\prime}\right)$ and GRGV-6850as (5'GCGCGGAATTTAAAGTGGG3') for the amplification of the $3^{\prime}$-terminal part of the replicase gene, the entire open reading frame 2 and the 3'UTR of the GRGV-Tab isolate (corresponding to approximately $40 \%$ of the viral genome), were used, and the resulting RT/

Shaheen Nourinejhad Zarghani

sh_nourinejhad@ut.ac.ir

1 Department of Plant Protection, College of Abouraihan, University of Tehran, 3391653755 Tehran, Iran

2 DLR Rheinpfalz, Institute of Plant Protection, Neustadt an der Weinstrasse, Germany

3 Department of Plant Protection, College of Agriculture and Natural Resources, University of Tehran, Karaj, Iran

4 UMR BFP, INRAE, University Bordeaux, Villenave d'Ornon, France
PCR products cloned and sequenced (MT591224-25). The resulting sequences of the GRGV-Tab isolate shared $85 \%$ and $93 \%$ identity at the nucleotide and $87 \%$ and $98 \%$ at the amino acid levels, respectively, with the corresponding sequences of the reference isolate. To our knowledge, this is the first report of GRGV in Iranian vineyards. Further studies will be necessary to assess its distribution nationwide and genetic diversity, as well as its potential threat to the grape production in Iran.

Funding This study was jointly supported by a Georg Foster Grant (Ref 3.4 -IRN/1186607, Alexander von Humboldt-Stiftung) and a grant from Iran National Science Foundation (grant number 94012607).

\section{References}

Abou Ghanem-Sabanadzovic N, Sabanadzovic S, Martelli GP (2003) Sequence analysis of the $3^{\prime}$ end of three Grapevine fleck viruslike viruses from grapevine. Virus Genes 27:11-16. https://doi. org/10.1023/A:1025164200412

Komínek P, Glasa M, Komínková M (2009) Analysis of multiple virus-infected grapevine plant reveals persistence but uneven virus distribution. Acta Virolo 53:281. https://doi.org/10.4149/ av_2009_04_281

Ruiz-García AB, Nourinejhad Zarghani S, Okic A, Olmos A, Wetzel $\mathrm{T}$ (2018) First report of grapevine red globe virus in grapevine in Germany. Plant Dis 102:1675. https://doi.org/10.1094/ PDIS-01-18-0105-PDN 